Section Editor: IGOR I. KAVASS

\title{
LAW LIBRARY CONFERENCES
}

The Canadian Association of Law Libraries will hold its next annual conference at McGill University in Montreal, May 20-24, 1980. For further information contact:

\author{
Professor Michael Renshawe \\ Law Library \\ McGill University \\ 3644 Peel Street \\ Montreal, Quebec H3A1W9 \\ CANADA
}

The 1980 Annual Meeting of the American Association Law Libraries will take place in St. Louis, June 21-25, 1980. The convention headquarters will be situated at the Chase-Park Plaza Hotel. For information about the program contact:

\begin{tabular}{|c|c|c|}
\hline \multirow{2}{*}{\multicolumn{2}{|c|}{$\begin{array}{l}\text { Professor Jane Hammond } \\
\text { Law Library }\end{array}$}} & Professor Bernard Reams, Jr \\
\hline & & Law Library \\
\hline Cornell University & or & Washington University \\
\hline Myron Taylor Hall & & Lindell and Skinner Blvds. \\
\hline Ithaca, New York 14853 & & St. Louis, MO 63130 \\
\hline USA & & USA \\
\hline
\end{tabular}

\section{INTERNATIONAL LAW ASSOCIATION CONFERENCE}

The 78th Conference of the International Law Association will be held in Belgrade, Yugoslavia, August 17-23, 1980. Dr. Milan Bulejic, Legal Adviser to the Yugoslav Foreign Office, is in charge of arrangements. Headquarters of the conference will be at the Intercontinental Hotel and meetings will be held at the Sava Conference Center next door. Conference fees are U.S. $\$ 100$ for members and U.S. $\$ 60$ for guests. 